\title{
Epigenetics and obesity: the devil is in the details
}

\author{
Paul W Franks ${ }^{1,2^{*}}$, Charlotte Ling ${ }^{1}$
}

\begin{abstract}
Obesity is a complex disease with multiple well-defined risk factors. Nevertheless, susceptibility to obesity and its sequelae within obesogenic environments varies greatly from one person to the next, suggesting a role for gene $x$ environment interactions in the etiology of the disorder. Epigenetic regulation of the human genome provides a putative mechanism by which specific environmental exposures convey risk for obesity and other human diseases and is one possible mechanism that underlies the gene $\times$ environment/treatment interactions observed in epidemiological studies and clinical trials. A study published in BMC Medicine this month by Wang et al. reports on an examination of DNA methylation in peripheral blood leukocytes of lean and obese adolescents, comparing methylation patterns between the two groups. The authors identified two genes that were differentially methylated, both of which have roles in immune function. Here we overview the findings from this study in the context of those emerging from other recent genetic and epigenetic studies, discuss the strengths and weaknesses of the study and speculate on the future of epigenetics in chronic disease research.

See research article: http://www.biomedcentral.com/1741-7015/8/87/abstract
\end{abstract}

\section{Introduction}

Obesity is highly prevalent in most industrialized nations where labor-saving devices and calorically dense diets are common [1]. The impressive results from randomized clinical trials of intensive lifestyle modification on short- to medium-term weight loss [2,3] give us good reason to believe that traditional hunter-gatherer or subsistence farming lifestyles might be a panacea for the obesity epidemic. However, programs of lifestyle modification are notoriously difficult to implement and maintain on a large scale for prolonged durations, and the public health message of "eat less and exercise more" appears to have fallen on deaf ears. Thus, despite the apparently simple explanation and remedy for obesity, this knowledge is not enough. So we are saddled with a challenge, which is to unravel the mechanisms by which obesity emerges and to understand how its presence causes disease and death, with the hope that somewhere within the details hides the solution to the problem.

Although obesity is widespread, certain ethnic groups appear much more susceptible than others to the condition [4]. Striking differences in the rates of obesity are

\footnotetext{
* Correspondence: paul.franks@med.lu.se

'Department of Clinical Sciences, Skåne University Hospital, Lund University, Malmö, Sweden

Full list of author information is available at the end of the article
}

often seen between genetically distinct subpopulations, such as American Indians and people of northern European ancestry living within comparable environments, indicating that obesity may be the consequence of gene $x$ environment interactions. More concrete evidence of such interactions has emerged from epidemiological cohort studies, most notably for the interaction between a polymorphism at the $F T O$ (fat mass and obesity gene) locus and physical activity levels [5]. Nevertheless, even where rare examples of statistically reliable gene $x$ environment interactions have emerged from epidemiological studies, causal inference is often difficult and little is revealed about the underlying mechanisms driving the interaction.

\section{Mechanisms of gene $x$ environment interactions in disease}

So what mechanisms might underlie the gene $\times$ environment interactions observed in epidemiological studies or clinical trials? Clearly, the manner in which an interaction is defined and quantified will affect our ability to understand the cellular mechanisms which underlie it. However, assuming the interaction is a consequence of environmental effects (for example, smoking, physical activity, or dietary whole grains intake) on a disease trait that are dependent on the genotype of an individual,
C Biomed Central

(c) 2010 Franks and Ling; licensee BioMed Central Ltd. This is an Open Access article distributed under the terms of the Creative Commons Attribution License (http://creativecommons.org/licenses/by/2.0), which permits unrestricted use, distribution, and reproduction in any medium, provided the original work is properly cited. 


\section{ENVIRONMENTAL TRIGGERS}

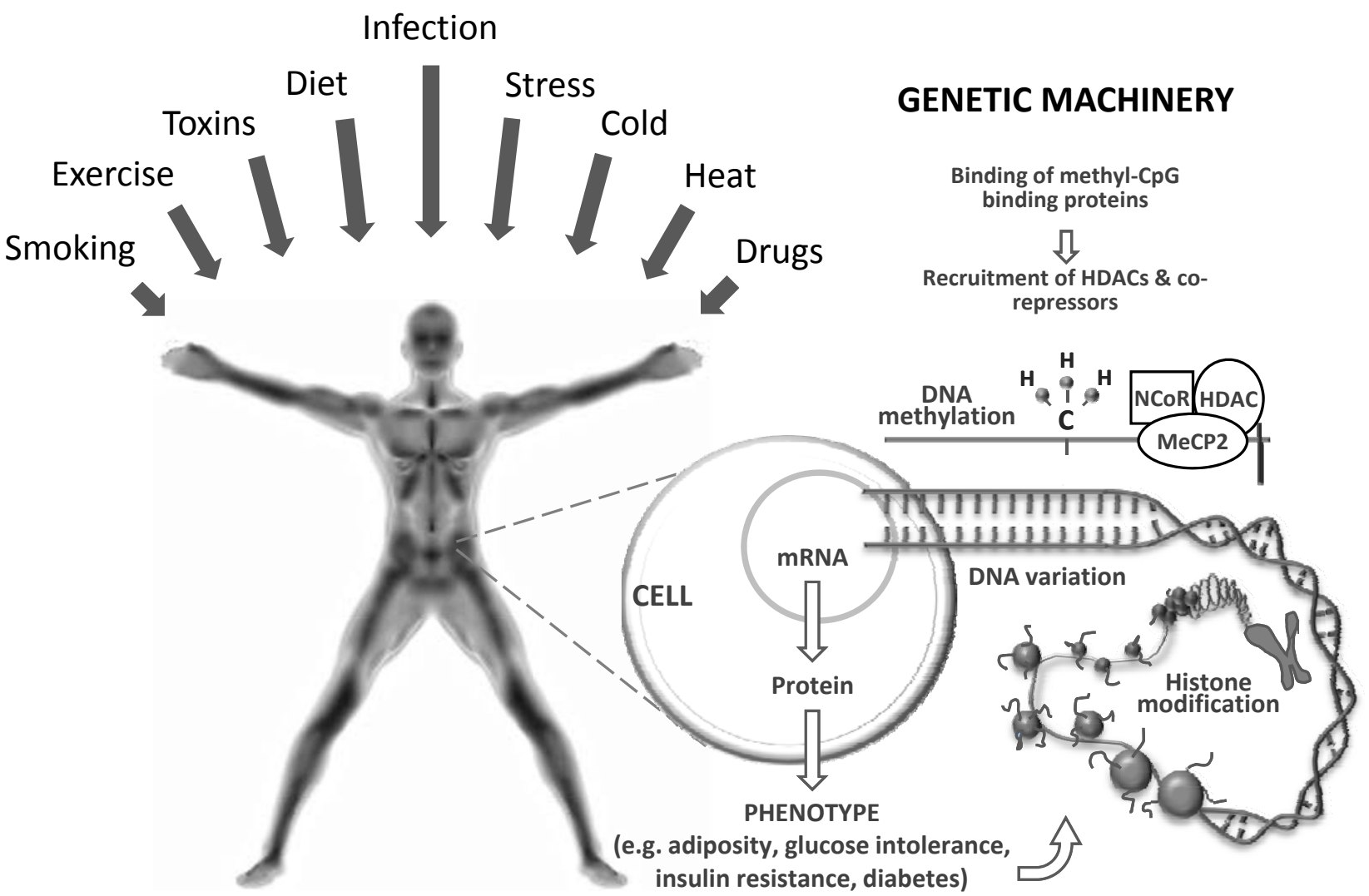

Figure 1 The mechanisms that underlie observations of gene $\times$ environment interactions made in epidemiological studies (or gene $\times$ treatment interactions in clinical trials) likely involve a combination of epigenetic and transcriptional modifications. Although environmental exposures may be the primary triggers of these perturbations, the phenotypes themselves may also feed back to trigger both epigenetic and transcriptomic events, thus modulating the expression of disease phenotypes. The figure shows a simplification of how these processes might fit together. HDAC, histone deacetyltransferase; NCor, nuclear receptor corepressor; MeCP2, methyl CpG binding protein 2.

there are probably at least two closely related mechanisms that might give rise to the interaction (Figure 1).

The first involves differential transcription rates across genotypes in response to environmental stimuli. During aerobic exercise, as an example, subsets of genes, particularly those involved in oxidative energy metabolism, are upregulated [6]. If the rates of transcription or translation of these genes were to differ by genotype, one might, at a population level, observe a gene $\times$ lifestyle interaction on a clinical phenotype such as blood glucose concentrations. The second mechanism by which genes and environmental factors might interact involves epigenetic factors, such as DNA methylation and histone modifications.

The word epigenetics describes the phenomena of inherited changes in gene function that occur independently of changes in the nucleotide sequence [7]. Initially, it was believed that epigenetic modifications were unidirectional, but recent studies have demonstrated that the epigenome is in fact highly dynamic, changing in response to nutrient availability, physical exercise and aging, among other exposures [8-22]. While nearly all cells in the body have the same nuclear genome, different cell types have their own epigenomes, a characteristic essential for the development of cell-specific phenotypes. In differentiated mammalian cells, DNA methylation occurs primarily to cytosines in CpGdinucleotides[23]. DNA methylation of gene promoters has also been implicated in transcriptional silencing, mainly through repressed transcription factor binding to gene promoters or by recruiting methyl-CG-binding proteins, which in turn recruit histone deacetyltransferases (HDACs) and corepressors. By virtue of the cell's capacity for histone modification, it can control its chromatin structure and either activate or suppress the transcription of its genes. Early-life nutrition represents an intriguing example of how environmentally augmented epigenetic events might affect an individual's response 
to metabolic load and disease susceptibility in adulthood, with numerous studies lending weight to this hypothesis [14-16,24,25]. Nevertheless, our understanding of how epigenetic events early in life influence the development of obesity and its comorbidities remains fairly rudimentary.

This month in BMC Medicine, Wang et al. [26] report a study in which they examined DNA methylation in isolated blood leukocytes and its relationship with obesity-induced immune dysfunction in seven lean and seven obese African American male adolescents. Specifically, the authors examined DNA methylation in peripheral blood leukocytes at approximately 27,000 CpG sites spread across more than 14,000 genes and compared methylation patterns between the two groups. Epigenetic studies are often constrained in their size by the high costs of the methylation chips (although this obstacle is receding as the technology becomes less expensive). This, in combination with the multitude of hypothesis tests that are performed in multiplex experiments and the corresponding procedures to correct for type 1 errors, render almost all existing epigenetic studies underpowered to detect statistically robust effects. Such is the case with the study conducted by Wang et al.; indeed, none of the findings from the first phase of their experiment remained statistically significant after correction for multiple testing. Despite this, the authors carried forward their most promising findings (defined as either genes yielding association $P$ values $\leq 2 \times 10^{-4}$ or those with differences in DNA methylation $\geq 27.1 \%$ ) for replication in a cohort composed of 45 obese and 46 lean individuals. In these replication analyses, two of six genes were differentially methylated in obese compared with lean individuals; the levels of DNA methylation for UBASH3A (ubiquitin-associated and $\mathrm{SH} 3$ domaincontaining A) and TRIM3 (tripartite motif-containing 3) were higher and lower, respectively, in obese compared with lean individuals, findings that were directionally consistent with those from the first phase of the study.

Interestingly, recent genome-wide scans have implicated DNA variants proximal to $U B A S H 3 A$, which encodes a $\mathrm{T}$-cell signaling- and activation-regulating protein [27], in the development of type 1 diabetes [28]. Thus, the findings of Wang et al., when placed in context with existing genetic data, suggest that $U B A S H 3 A$ may play a role in obesity-induced immune dysfunction. Intriguingly, TRIM3, which belongs to the superfamily of TRIM proteins, is also involved in immune response [29], which may explain why differential methylation patterns of these genes were visible in blood leukocytes.

The study by Wang et al. is small and probably underpowered to detect all but the largest differences in DNA methylation. It may be, therefore, that with a larger sample size, statistically significant differences in
DNA methylation patterns for many other genes that are smaller in magnitude than for $U B A S H 3 A$ and TRIM1 would be observable. The detection of other CpG sites and genes might also be facilitated by the application of methods that afford greater genomic coverage, such as deep sequencing combined with either bisulfite-treated DNA or immunoprecipitation of methylated DNA.

While peripheral blood leukocytes are attractive for epigenetic studies, not least because they can be easily obtained, there are many other cell types and tissues involved in the pathogenesis of obesity and its comorbidities, such as adipose tissue, skeletal muscle and hypothalamus, the examination of which could be well worthwhile in the context of epigenetics. Along these lines, Bouchard et al. [17] recently provided some of the first evidence that DNA methylation in adipose tissue differs in people who respond well and those who respond poorly to caloric restriction for weight loss. Elsewhere, a high-fat diet lasting 5 days was shown to affect DNA methylation of a major transcriptional coactivator (peroxisome proliferator-activated receptor- $\gamma$ coactivator $1-\alpha$ ) of genes involved in oxidative energy metabolism [13]. Furthermore, in studies examining early life overnutrition and obesity, DNA methylation of the hyperthalamically expressed pro-opiomelanocortin promoter, which plays an important role in hunger and satiation [30], was observed. While these studies imply that epigenetic modifications cause obesity, metabolic disease and its complications, it is virtually impossible to establish whether changes in methylation precede the development of obesity or vice versa. Indeed, these relationships may not be causal at all, but consequences of confounding by factors correlated with obesity and DNA methylation, such as physical inactivity, nutrition or smoking.

Elucidating causal relationships between DNA methylation and obesity will be necessary if observations of the nature described by Wang et al. are to be of clinical value. Inevitably, this probably means that randomized, controlled trials of weight loss or weight gain interventions, where DNA methylation patterns are assessed before and after the intervention and subsequently compared between the treatment and control arms of the trial, are required. It will also be necessary to examine whether changes in DNA methylation correspond with changes in gene transcription and/or translation, as well as more distal, clinically relevant phenotypes. Assessing these relationships in diverse tissues and cell types and in different demographic groups and environmental contexts will further advance our understanding of how epigenetic events affect an individual's predisposition to obesity, or how obesity impacts the epigenome. Whether changes in DNA methylation are associated with 
obesity-induced histone modifications of the same genes (that is, whether DNA methylation coincides with the presence of closed histone marks) represents another interesting but as yet unanswered question.

\section{Concluding remarks}

In summary, Wang et al.'s study provides tentative evidence that DNA methylation at two loci, UBASH3A and TRIM3, may be implicated in the pathogenesis of obesity. Replication of these findings in independent settings will be necessary to ensure that these findings are true positives, and to fairly conclude that the relationships are causal will require appropriately designed experimental studies. Because of these and other hurdles facing the field of epigenetics, identifying a meaningful clinical application for epigenetics in the prevention or treatment of obesity is likely to remain more vision than reality for some time to come.

\section{Acknowledgements}

Both authors were supported in part by grants from the Swedish Research Council, Novo Nordisk and Swedish Diabetes Association, and PWF was supported by grants from the Swedish Heart Lung Foundation.

\section{Author details}

'Department of Clinical Sciences, Skåne University Hospital, Lund University, Malmö, Sweden. ²Department of Nutrition, Harvard School of Public Health, Boston, MA, USA.

\section{Authors' contributions}

PWF wrote the first draft of the article. Both authors contributed to the development of the draft.

\section{Competing interests}

The authors declare that they have no competing interests.

Received: 1 November 2010 Accepted: 21 December 2010

Published: 21 December 2010

\section{References}

1. World Health Organization: Global Health Risks: Mortality and Burden of Disease Attributable to Selected Major Risk Factors Geneva, Switzerland: World Health Organization; 2009

2. Knowler WC, Barrett-Connor E, Fowler SE, Hamman RF, Lachin JM, Walker EA, Nathan DM: Reduction in the incidence of type 2 diabetes with lifestyle intervention or metformin. N Engl J Med 2002, 346:393-403.

3. Tuomilehto J, Lindstrom J, Eriksson JG, Valle TT, Hamalainen H, llanneParikka P, Keinanen-Kiukaanniemi S, Laakso M, Louheranta A, Rastas M, Salminen V, Aunola S, Cepaitis Z, Moltchanov V, Hakumaki M, Mannelin M, Martikkala V, Sundvall J, Uusitupa M, Finnish Diabetes Prevention Study Group: Prevention of type 2 diabetes mellitus by changes in lifestyle among subjects with impaired glucose tolerance. N Engl J Med 2001, 344:1343-1350.

4. Ogden $C L$, Carroll MD, Curtin LR, McDowell MA, Tabak CJ, Flegal KM: Prevalence of overweight and obesity in the United States, 1999-2004. JAMA 2006, 295:1549-1555.

5. Andreasen $\mathrm{CH}$, Stender-Petersen KL, Mogensen MS, Torekov SS, Wegner $\mathrm{L}$, Andersen G, Nielsen AL, Albrechtsen A, Borch-Johnsen K, Rasmussen SS, Clausen JO, Sandbaek A, Lauritzen T, Hansen L, Jorgensen T, Pedersen O, Hansen T: Low physical activity accentuates the effect of the FTO rs9939609 polymorphism on body fat accumulation. Diabetes 2008, 57:95-101.

6. Franks PW, Loos RJ: PGC-1alpha gene and physical activity in type 2 diabetes mellitus. Exerc Sport Sci Rev 2006, 34:171-175.
7. Bird A: Perceptions of epigenetics. Nature 2007, 447:396-398.

8. McGee SL, Hargreaves M: Exercise and myocyte enhancer factor 2 regulation in human skeletal muscle. Diabetes 2004, 53:1208-1214.

9. McGee SL, Hargreaves M: Exercise and skeletal muscle glucose transporter 4 expression: molecular mechanisms. Clin Exp Pharmacol Physiol 2006, 33:395-399.

10. McGee SL, Howlett KF, Starkie RL, Cameron-Smith D, Kemp BE, Hargreaves M: Exercise increases nuclear AMPK $a_{2}$ in human skeletal muscle. Diabetes 2003, 52:926-928.

11. McGee SL, Sparling D, Olson AL, Hargreaves M: Exercise increases MEF2and GEF DNA-binding activity in human skeletal muscle. FASEB J 2006, 20:348-349.

12. McGee SL, van Denderen BJ, Howlett KF, Mollica J, Schertzer JD, Kemp BE, Hargreaves M: AMP-activated protein kinase regulates GLUT4 transcription by phosphorylating histone deacetylase 5. Diabetes 2008, 57:860-867.

13. Brøns $C$, Jacobsen $S$, Nilsson $E$, Rönn $T$, Jensen $C B$, Storgaard $H$, Poulsen $P$, Groop L, Ling C, Astrup A, Vaag A: Deoxyribonucleic acid methylation and gene expression of PPARGC1A in human muscle is influenced by highfat overfeeding in a birth-weight-dependent manner. J Clin Endocrinol Metab 2010, 95:3048-3056.

14. Lillycrop KA, Phillips ES, Jackson AA, Hanson MA, Burdge GC: Dietary protein restriction of pregnant rats induces and folic acid supplementation prevents epigenetic modification of hepatic gene expression in the offspring. J Nutr 2005, 135:1382-1386.

15. Lillycrop KA, Phillips ES, Torrens C, Hanson MA, Jackson AA, Burdge GC: Feeding pregnant rats a protein-restricted diet persistently alters the methylation of specific cytosines in the hepatic PPAR alpha promoter of the offspring. Br J Nutr 2008, 100:278-282.

16. Lillycrop KA, Slater-Jefferies $J$, Hanson MA, Godfrey KM, Jackson AA, Burdge GC: Induction of altered epigenetic regulation of the hepatic glucocorticoid receptor in the offspring of rats fed a protein-restricted diet during pregnancy suggests that reduced DNA methyltransferase-1 expression is involved in impaired DNA methylation and changes in histone modifications. Br J Nutr 2007, 97:1064-1073.

17. Bouchard L, Rabasa-Lhoret R, Faraj M, Lavoie ME, Mill J, Pérusse L, Vohl MC: Differential epigenomic and transcriptomic responses in subcutaneous adipose tissue between low and high responders to caloric restriction. Am J Clin Nutr 2010, 91:309-320.

18. Fraga MF, Ballestar E, Paz MF, Ropero S, Setien F, Ballestar ML, HeineSuner D, Cigudosa JC, Urioste M, Benitez J, Boix-Chornet M, SanchezAguilera A, Ling C, Carlsson E, Poulsen P, Vaag A, Stephan Z, Spector TD, Wu YZ, Plass C, Esteller M: Epigenetic differences arise during the lifetime of monozygotic twins. Proc Natl Acad Sci USA 2005, 102:10604-10609.

19. Ling C, Groop L: Epigenetics: a molecular link between environmental factors and type 2 diabetes. Diabetes 2009, 58:2718-2725.

20. Ling C, Del Guerra S, Lupi R, Rönn T, Granhall C, Luthman H, Masiello P, Marchetti P, Groop L, Del Prato S: Epigenetic regulation of PPARGC1A in human type 2 diabetic islets and effect on insulin secretion. Diabetologia 2008, 51(4):615-22.

21. Ronn T, Poulsen P, Hansson O, Holmkvist J, Almgren P, Nilsson P, Tuomi T, Isomaa B, Groop L, Vaag A, Ling C: Age influences DNA methylation and gene expression of COX7A1 in human skeletal muscle. Diabetologia 2008, 51:1159-1168.

22. Ling C, Poulsen P, Simonsson S, Ronn T, Holmkvist J, Almgren P, Hagert P, Nilsson E, Mabey AG, Nilsson P, Vaag A, Groop L: Genetic and epigenetic factors are associated with expression of respiratory chain component NDUFB6 in human skeletal muscle. J Clin Invest 2007, 117:3427-3435.

23. Lister R, Pelizzola M, Dowen RH, Hawkins RD, Hon G, Tonti-Filippini J, Nery JR, Lee L, Ye Z, Ngo QM, Edsall L, Antosiewicz-Bourget J, Stewart R, Ruotti V, Millar AH, Thomson JA, Ren B, Ecker JR: Human DNA methylomes at base resolution show widespread epigenomic differences. Nature 2009, 462:315-322.

24. Tobi EW, Lumey LH, Talens RP, Kremer D, Putter H, Stein AD, Slagboom PE, Heijmans BT: DNA Methylation differences after exposure to prenatal famine are common and timing- and sex-specific. Hum Mol Genet 2009, 18:4046-4053.

25. Heijmans BT, Tobi EW, Stein AD, Putter H, Blauw GJ, Susser ES, Slagboom PE, Lumey LH: Persistent epigenetic differences associated with prenatal exposure to famine in humans. Proc Natl Acad Sci USA 2008, 105:17046-17049. 
26. Wang X, Zhu H, Sneider H, Su S, Munn D, Harshfiels G, Maria BL, Dong Y, Treiber F, Gutin B, Shi H: Obesity related methylation changes in DNA of peripheral blood leukocytes. BMC Med 2010, 8:87.

27. Carpino N, Turner S, Mekala D, Takahashi Y, Zang H, Geiger TL, Doherty $P$, Ihle JN: Regulation of ZAP-70 activation and TCR signaling by two related proteins, Sts-1 and Sts-2. Immunity 2004, 20:37-46.

28. Barrett JC, Clayton DG, Concannon P, Akolkar B, Cooper JD, Erlich HA, Julier C, Morahan G, Nerup J, Nierras C, Plagnol V, Pociot F, Schuilenburg H, Smyth DJ, Stevens H, Todd JA, Walker NM, Rich SS: Genome-wide association study and meta-analysis find that over 40 loci affect risk of type 1 diabetes. Nat Genet 2009, 41:703-707.

29. Ozato K, Shin DM, Chang TH, Morse HC: TRIM family proteins and their emerging roles in innate immunity. Nat Rev Immunol 2008, 8:849-860.

30. Plagemann A, Harder T, Brunn M, Harder A, Roepke K, Wittrock-Staar M, Ziska T, Schellong K, Rodekamp E, Melchior K, Dudenhausen JW: Hypothalamic proopiomelanocortin promoter methylation becomes altered by early overfeeding: an epigenetic model of obesity and the metabolic syndrome. J Physiol 2009, 587:4963-4976.

\section{Pre-publication history}

The pre-publication history for this paper can be accessed here: http://www.biomedcentral.com/1741-7015/8/88/prepub

doi:10.1186/1741-7015-8-88

Cite this article as: Franks and Ling: Epigenetics and obesity: the devil is in the details. BMC Medicine 2010 8:88.

\section{Submit your next manuscript to BioMed Central and take full advantage of:}

- Convenient online submission

- Thorough peer review

- No space constraints or color figure charges

- Immediate publication on acceptance

- Inclusion in PubMed, CAS, Scopus and Google Scholar

- Research which is freely available for redistribution

Submit your manuscript at www.biomedcentral.com/submit 